原著論文

\title{
各種補強材によるレジン床義歯の補強効果について
}

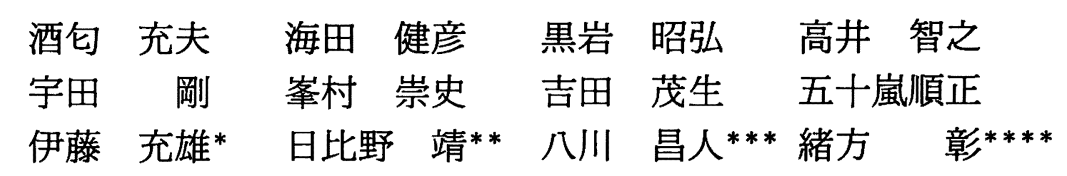

\section{Effect of Various Reinforcing Materials for Resin Denture Base}

Sakoh Mitsuo, Kaida Takehiko, Kuroiwa Akihiro, Takai Tomoyuki,

Uda Go, Minemura Takashi, Yoshida Shigeo, Igarashi Yoshimasa, Ito Michio*, Hibino Yasushi**, Hachikawa Masato*** and Ogata Akira****

\section{歯科補綴学的意義}

PMMA (Polymethylmethacrylate) レジンは義歯床用材料として，その操作性の簡便さから広く臨床で用いられてい る。しかしながら、レジン床義歯においては義歯床への応力集中による破折防止のため, 補強線を使用することが あるが, かえって補強線が破折を誘導したような状態を呈することが見受けられる. 本研究は、レジン床義歯補強 に適した材料を選択することを目的とし，各種傤維製補強材ならびに金属製補強線の補強効果の比較検討を行った ものである.

\section{抄 録}

目的：PMMA（Polymethylmethacrylate）レジンは広く臨床で用いられているが，義歯床の強度を 増加する必要が生じた場合，補強線を用いることが多い。しかしながら，義歯の破折線は補強線に沿っ て発生する傾向が見受けられ，この一因子として，補強線とPMMAレジンが化学的に結合していな いことが考えられる．これに対し，臨床においては金属接着プライマーや 4-META (4-methacryloxyethyl trimellitate anhydride) 含有レジンなどを用い, 補強線と床用レジンとの接着を求めてきた. 本研究は，レジン床義歯に対する補強効果を検討する目的で，瀻維製補強材ならびに金属製補強芯を用 い, それぞれの補強効果を比較検討した。

方法：三点曲げ試験，レジンの填入圧による繊維製補強材の断面積変化および色素浸入試験を行い，熱 サイクル負荷の有無について検討した。

結果：熱サイクル負荷を加えない試料の三点曲げ試験の結果，コントロールと比較し，Connect， Fiber-Splint は近似した值となり, そのほかの補強材は若干高い值を示した. 各種織維製補強材は低 加圧状態で重合した場合と比較し，加圧することにより圧縮されることが確認された。色素浸入試験の 結果, 熱サイクル負荷を加えない場合, Ribbond, Connect, Fiber-Splintに色素漫入が認められた が, Vectris, 補強芯では認められなかった。 また, 熱サイクル負荷を加えた場合, Vectris を除く瀻 維製補強材の色素浸入量が増加した。

和文キーワード

レジン床，補強材，曲げ強さ，色素浸入量

松本歯科大学歯科補綴学第 1 講座（主任：五十嵐順正教授）

*松本歯科大学歯科理工学講座

**明海大学歯学部歯科材料学講座

***東京支部（八川歯科医院）

****関西支部（おがた歯科）

Department of Removable Prosthodontics, School of Dentistry, Matsumoto Dental University (Chief : Prof. Igarashi Yoshimasa)

*Department of Dental Materials, School of Dentistry, Matsumoto Dental University

**Department of Dental Materials Science, Meikai University School of Dentistry

***Tokyo Branch (Hachikawa Dental Clinic)

****Kansai Branch (Ogata Dental Clinic)

受付: 2002 年 8 月 8 日/受理：2004 年 6 月 18 日

Received on August 8, 2002/Accepted on June 18, 2004 


\section{I. 緒言}

臨床において補強線を埋入したレジン床義歯に義歯 破折や破折線を確認することが多く，常に適切に補強 線が用いられているとは考え難い。この原因として, 補強線と床用レジンが化学的に結合していないこと, 補強線の埋入位置が十分に検討されていないこと，金 属床義歯適応症例に対し，レジンと補強線を組合せ使 用している症例が多数認められることなどが考えられ る.

化学的結合に対しては，金属接着プライマーや4methacryloxyethyl trimellitate anhydride (4META）含有レジンの使用が1)，補強線の埋入位置に ついては，レジンの上部または下部に埋入すると中心 部に埋入した場合と比較し，高い曲げ強さを示すこと が報告されている2).

本研究では, 各種補強材によるレジン床義歯の補強 効果を検討する目的で, 現在市販されている各種繊維 製補強材ならびに従来の金属製補強線を用い，床用レ ジンに埋入し，三点曲げ試験，レジンの填入圧による 各種補強材の断面積変化および色素浸入試験を行い, その有効性を検討した。

\section{II. 材料と方法}

\section{1. 実験材料}

表 1 に実験に用いた材料を示す，床用レジンには Polymethylmethacrylate（以下 PMMA）系加熱重 合型床用レジン ACRON (ジーシー, 以下 AC) No. 5 を用い, 各種繊維製補強材のなかからポリエチレン ファイバー製補強材として, Ribbond（RIBBOND, 以下 Ri), Connect (SYBRON, 以下 $\mathrm{Co})$, グラス ファイバー製補強材として, Fiber-Splint（POLYDENTIA, 以下 FS), Targis-Vectris system のな かからガラス繊維強化材である FRC 材の Vectris よ り Vectris Frame (Ivoclar, 以下 Ve), 従来の金属 製補強材より補強芯（デンツプライ三金，以下 Wi） を選択し，比較対照として補強材を埋入しない $\mathrm{AC}$ (以下 Cont.) を用いた。

さらに補強材の表面処理の影響について知るため, 補強材を $\mathrm{AC}$ のモノマーに浸漬したものを接着剤な
しとし, Co の接着剤であるConnect-Resin（SYBRON）を塗布し, 光重合器PETITLIGHT PL-1（ジーシー）にて 3 秒間光照射したものを $(\mathrm{Ri}+)$, 以下同様に $(\mathrm{Co}+, \mathrm{FS}+, \mathrm{Ve}+)$ とした。 $\mathrm{Wi}$ は平均粒径 $50 \mu \mathrm{m}$ のアルミナ粒子（以下アルミナ 50）を使用し, サンドブラスト処理を行ったのち, 歯 科用接着材料 Super-Bond opaque-Pink（サンメ ディカル, 以下 $\mathrm{SB}$ ) を用い (以下 $\mathrm{Wi}+$ ), 接着剤あ りとした。

また，AC の填入圧による各種補強材の断面積変化 を検討する目的で低加圧時の断面積を積算するため, PMMA 系常温重合レジン UNIFAST II（ジーシー, 以下 UN）のClearを用いた。

\section{2. 試料の製作}

表 2 に重合条件ならびに測定条件を示す。各種補強 材のうち, Ri, Co, FS, Wi は幅 $2 \mathrm{~mm}$ のものを選 択した.Ve は単一では試料の長さに達しないため, VeをVectris VS 1 (Ivoclar) にて重合後, $2 \pm 0.03$ $\mathrm{mm}$ に調整し，アルミナ 50 を用い， 2 気圧にてサン ドブラスト処理を行い，スチーム洗浄を行った。その 後, Vectris 用 Wetting agentを塗布し, 60 秒間放 置, エアーにて乾燥後, Vectris Pontic (Ivoclar) をVeの左右に置き，再度 Vectris VS 1 にて重合を 行い, 厚さ, 幅を調整し実験に供した。

各種補強材の埋入位置は試料の深さの中央とし, 繊 維製補強材の取り扱いにおいては，補強材が污染され ぬよう Ribbondに同封されたコットングローブを装 着し，製作にあたった。

図 1 に三点曲げ試験の試料を示す.試料の製作は, JIS T 6501 の規格に準拠した $65 \times 10 \times 3 \mathrm{~mm}$ のゴム 型を石高に埋没し, 石高硬化後ゴム型を除去し, $\mathrm{AC}$ を填入し, 各種補強材を固定したのち, 再度圧接し重 合を行った.

各種補強材の断面積変化を求める試料の製作は, UN にて低加圧で重合した試料と AC にて加圧重合し た試料を製作した。

図 2 に色素侵入試験の試料ならびに測定部位を示 す．試料の製作は補強材の幅を考慮し， $30 \times 2 \times 5 \mathrm{~mm}$ のゴム型を石高に埋没し, 石膏硬化後ゴム型を除去 し, レジンを填入し, 各種補強材を固定したのち, 再 度圧接し重合を行った。 
表 1 Materials used in this study

本実験に使用したレジン，補強材ならびに接着剂

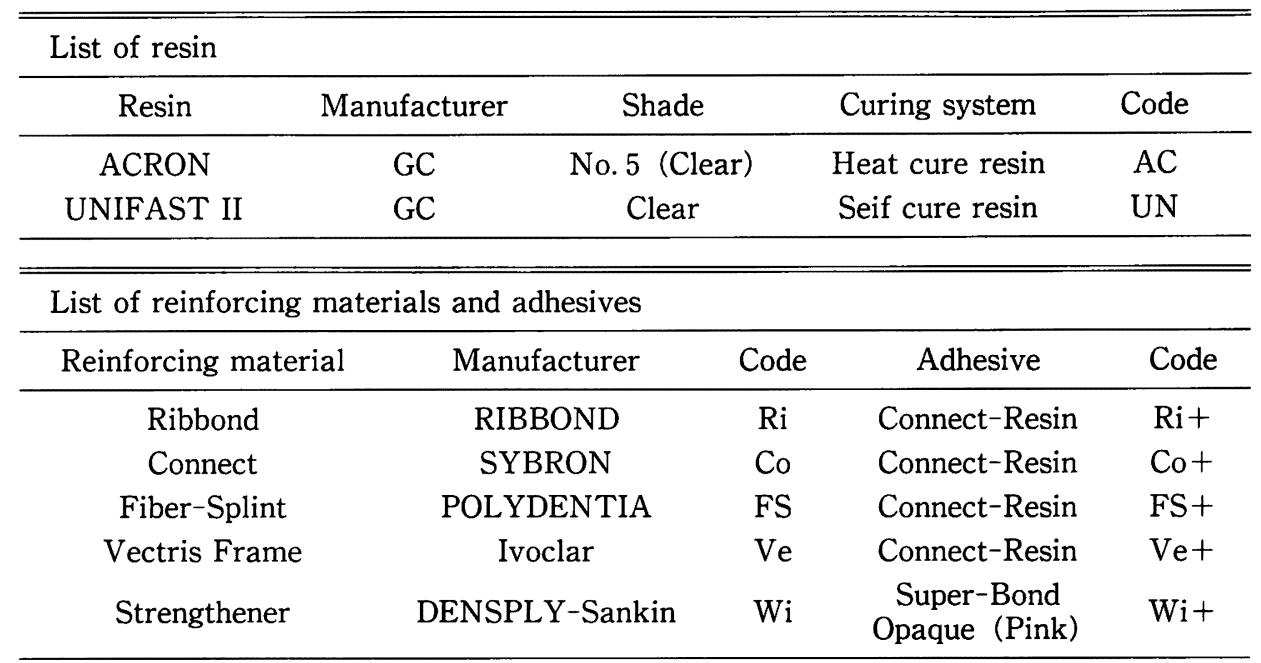

表 2 Methods for testing reinforcing materials in denture base resin 重合条件ならびに測定条件

Denture base resin Curing condition

$65^{\circ} \mathrm{C}: 60 \mathrm{~min}, 100^{\circ} \mathrm{C}: 30 \mathrm{~min}$, Cooling time $: 12$ hours

\begin{tabular}{|c|c|c|}
\hline Measurement & Testing machine and testing conditions & Size of specimen \\
\hline Flexual strength test & $\begin{array}{l}\text { AUTO GRAPH AG- } 5000 \mathrm{D} \text {, Span } 50 \mathrm{~mm} \text {, } \\
\text { Cross-head speed } 5 \mathrm{~mm} / \mathrm{min}\end{array}$ & $65 \times 10 \times 3$ \\
\hline Dye penetration test & $\begin{array}{l}\text { PROFILE PROJECTOR PJ } 311,3 \% \text { aqueous } \\
\text { solution of basic fuchsin dye for } 72 \mathrm{~h}\end{array}$ & $30 \times 2 \times 5$ \\
\hline
\end{tabular}

unit : mm

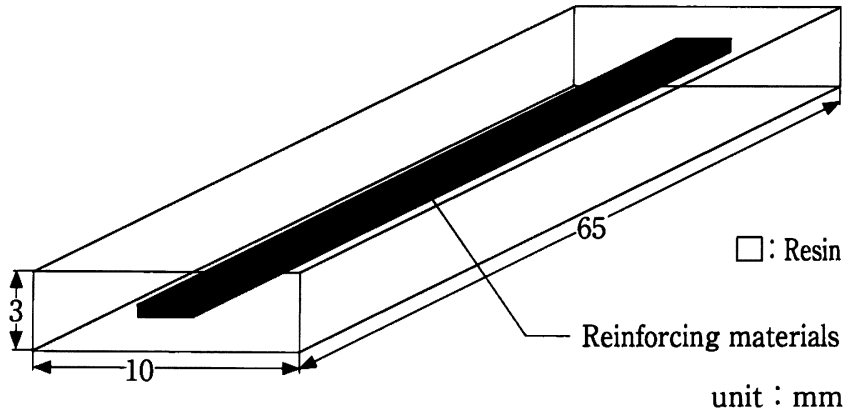

図 1 Size of specimen for flexural strength 三点曲げ試験用試料

なお，すべての試料において AC の最終加圧は 50 $\mathrm{kg} / \mathrm{cm}^{2}$ とした。

試料は重合後，エメリー研磨（800 番）を施し，各 条件において 5 個ずつ製作し， $37^{\circ} \mathrm{C}$ の精製水中に 2 週間浸漬した後，実験に供した。

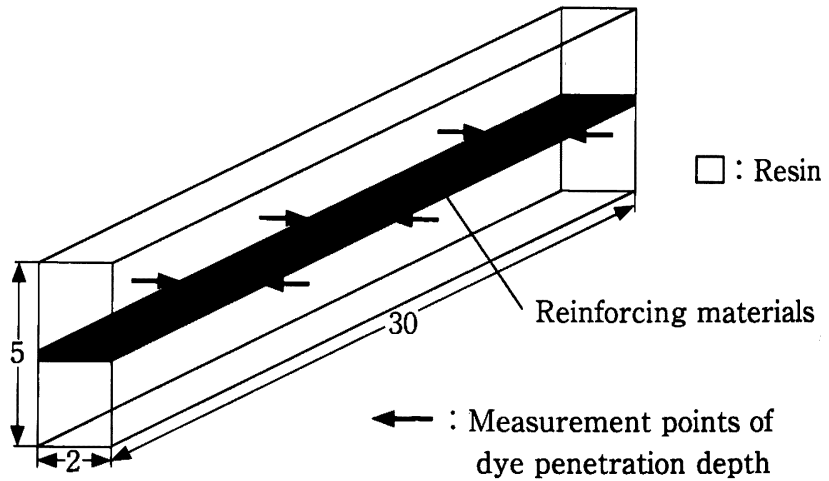

unit : mm

図 2 Size of specimen for dye penetration 色素侵入試験用試料

\section{3. 実験方法}

三点曲げ試験は，熱サイクル負荷を加えない試料 と, サーマルサイクル試験機（イトウエンジニアリン 
グ）を用い, $4^{\circ} \mathrm{C}, 60^{\circ} \mathrm{C}$, 各係留時間, 1 分間の条件 で 3,000 回熱サイクル負荷を加えた試料を用意した。 測定は万能試験機 AG-5000 D（島津製作所）を用い, 支点間距離 $50 \mathrm{~mm}$, 最大荷重 $5 \mathrm{kgf}$, クロスヘッドス

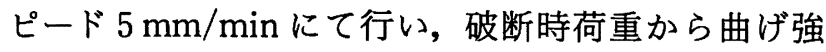
さを求めた。

各種補強材の断面積変化はUN にて低加圧で重合 した試料と ACにより加圧重合した試料を製作し, レジン重合後試料を切断したのち, 各種補強材の断面 積変化を検討した。

色素浸入試験は三点曲げ試験と同様に，熱サイクル 負荷を加えない試料と加えた試料を用意した。 $3 \%$ 塩 基性フクシン溶液に浸漬後, 試料表層のフクシン溶液 を洗い流し，万能投影機 PROFILE PROJECTOR PJ 311 (ミツトヨ) にて, 1 試料につき 6 点を計測 し，その平均値を算出し色素浸入量とした（図 2). なお, 浸漬時間については予備実験を行い, 試料間の 色素浸入量に差異の認められた 72 時間とした。

\section{4. 統計分析}

得られた計測值を統計ソフトウェア Stat Mate III (アトムス) にて Kruskal-Wallis (Tukey-type) に より統計解析を行い検討した.

\section{III. 実験結果}

\section{1. 三点曲げ試験について}

熱サイクル負荷を加えない試料の結果を図 3 に, 熱 サイクル負荷を加えた試料の結果を図 4 に示す.

熱サイクル負荷を加えない場合, Cont., Co, FS, Wi は近似した曲げ強さを示し，そのほかの補強 材は若干高い曲げ強さを示した。 また, 接着剤を使用 することにより, 䋞維製補強材の曲げ強さは増加した が，Wi+は低下傾向を示した。統計解析を行った結 果, Cont.に対 ᄂ, $\mathrm{Co}+, \mathrm{FS}+, \mathrm{Ve}, \mathrm{Ve}+, \mathrm{Wi}+$ において有意差が認められた。

熱サイクル負荷を加えた場合, Cont.の曲げ強さは 著しく低下した。また, 統計解析を行った結果, Cont.に対し, $\mathrm{Co}+, \mathrm{FS}+, \mathrm{Ve}, \mathrm{Ve}+, \mathrm{Wi}+に お$ いて有意差が認められた。接着剤の有無で比較する と, Ve を除く補強材は低下傾向を示した.

\section{2. 各種補強材の断面積変化について}

低加圧にて重合した試料と加圧重合した試料の補強 材の断面積を表 3 に示す. 瀻維製補強材は加圧重合す ることにより圧縮されており，Ri，Co では約 19\%, Ve は約 $52 \%, F S$ は約 $85 \%$ の断面積減少率であっ た.また，接着剤を用いると $\mathrm{Ri}+, \mathrm{FS}+, \mathrm{Ve}+$ の断

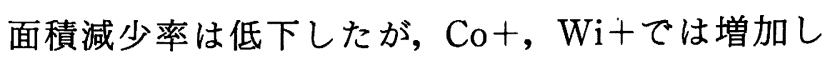
た.

\section{3. 色素浸入試験について}

熱サイクル負荷を加えない試料の結果を図 5 に, 熱 サイクル負荷を加えた試料の結果を図 6 に示す。

熱サイクル負荷を加えない場合, 色素浸入は Ri, $\mathrm{Co}, \mathrm{FS}, \mathrm{FS}+て ゙$ 認められたが, $\mathrm{Ve}, \mathrm{Ve}+, \mathrm{Wi}$, $\mathrm{Wi}+$ +で認められなかった。また，接着郕塗布によ る色素浸入量の変化では, 同一補強材間において有意 差は認められなかった。

熱サイクル負荷を加えた場合, Ri，Co, FS の色素 浸入量が増加し, $\mathrm{Ve}, \mathrm{Ve}+, \mathrm{Wi}, \mathrm{Wi}+$ では熱サイ クル負荷を加えない場合と同様に，色素浸入は認めら れなかった。 また, 接着剤塗布による色素浸入量の変 化をみると, 接着剤が効果を発揮したのは Co十の であり, Ri+は接着剤の効果を得ることができず, FS+は色素進入量が増加した。

\section{IV. 考察}

\section{1. 実験材料について}

レジン床義歯の補強に関しては，金属製補強線を用 いたもの 3 5)や繊維を用いたもの 研究がなされ, 近年ではグラスファイバーによる補強 効果について多くの研究がなされている8 14).

現在,さまざまな繊維製補強材が市販され, 動摇歯 や移植歯の固定, 欠損歯接着修復, メタルフリーブ リッジの製作，プロビジョナル・レストレーションの 補強, 義歯修理およびレジン床義歯補強などさまざま な用途に使用できる. また，それぞれの用途によりい くつかの幅の補強材が用意されている.

緘維製補強材は, 古くは前記の報告のようにカーボ ンファイバーを全部床義歯の補強材として用いた研究 がなされたが6,7), 粘膜面へのファイバーの露出が問 題となり, 臨床へは生かされなかった。現在では義歯 


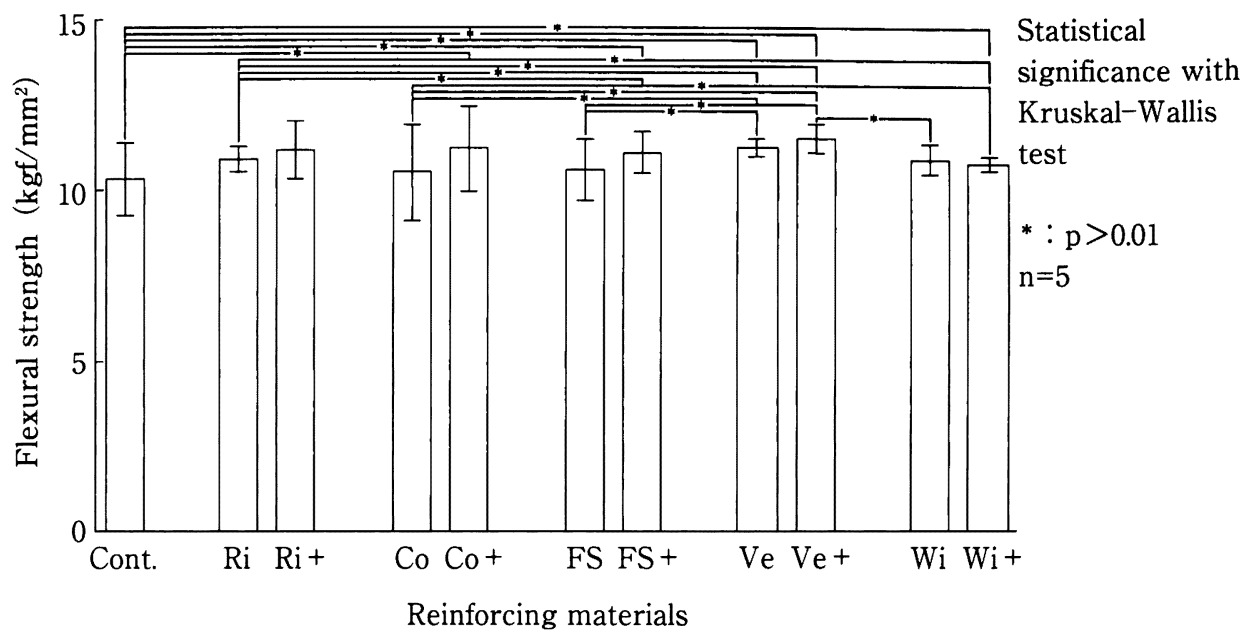

図 3 Effect of reinforcing materials on the mechanical properties (without thermal cycling test)

三点曲げ試験の結果（熱サイクル負荷：なし）

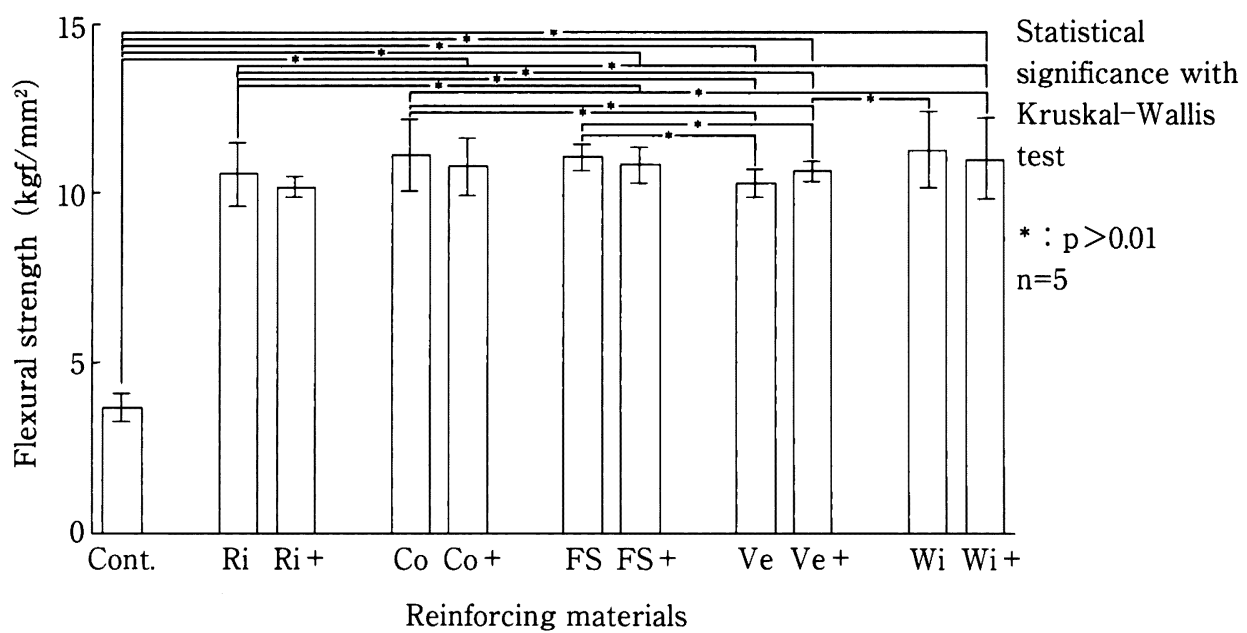

図 4 Effect of reinforcing materials on the mechanical properties (with thermal cycling test)

三点曲げ試験の結果（熱サイクル負荷：あり）

ではなくクラウン・ブリッジのフレームやメタルコア に替わるコア材としての需要が高まっており，ポリエ チレンファイバー製とグラスファイバー製補強材があ る. 多くの繊維製補強材は柔軟性のある帯状形態であ るが, Veはほかの補強材と比較し，柔軟性は低い。 もっとも，そのほかの繊維製補強材もメタルフリーブ リッジなどに使用する場合，レジンにてコーティング するため，柔軟性は低くなる。

接着剂は，SYBRONより Bis-GMA を基材とした Connect-Resin, Ivoclar では Targis-Vectris system としてWetting agent が販売され，そのほかの
補強材では即時重合レジンを Sticky 状に塗布し，接 着させる方法が推奨されている，即時重合レジンは試 料によって粉液比が異なる可能性があり，本実験では 常に均一な接着剤である Connect-Resin を選択した。

\section{2. 実験方法について}

本実験では補強材は幅 $2 \mathrm{~mm}$ のものを選択したが, 繊維製補強材ではレジン床義歯の補強を目的とする場 合，幅の広いものを使用することとなっている，この ため，実際のレジン床義歯の補強効果とは異なること が考えられる。 
表 3 Sectional area of reinforcing materials 各種補強材の断面積変化

\begin{tabular}{|c|c|c|c|c|c|c|c|c|c|c|}
\hline \multicolumn{11}{|c|}{ Non pressure (Self cure resin) } \\
\hline $\begin{array}{l}\text { Reinforcing } \\
\text { materials }\end{array}$ & $\mathrm{Ri}$ & $\mathrm{Ri}+$ & Co & Cot & FS & FS+ & $\mathrm{Ve}$ & $\mathrm{Ve}+$ & $\mathrm{Wi}$ & Wit \\
\hline Sectional area & 0.76 & 0.89 & 0.73 & 0.97 & 3.14 & 0.53 & 0.91 & 1.06 & 1.72 & 4.24 \\
\hline \multicolumn{11}{|c|}{ Pressure (Heat cure resin) } \\
\hline $\begin{array}{l}\text { Reinforcing } \\
\text { materials }\end{array}$ & $\mathrm{Ri}$ & $\mathrm{Ri}+$ & Co & $\mathrm{Co}+$ & FS & FS+ & $\mathrm{Ve}$ & $\mathrm{Ve}+$ & $\mathrm{Wi}$ & $\mathrm{Wi}+$ \\
\hline Sectional area & 0.62 & 0.81 & 0.59 & 0.68 & 0.46 & 0.29 & 0.43 & 0.55 & 1.57 & 3.14 \\
\hline
\end{tabular}
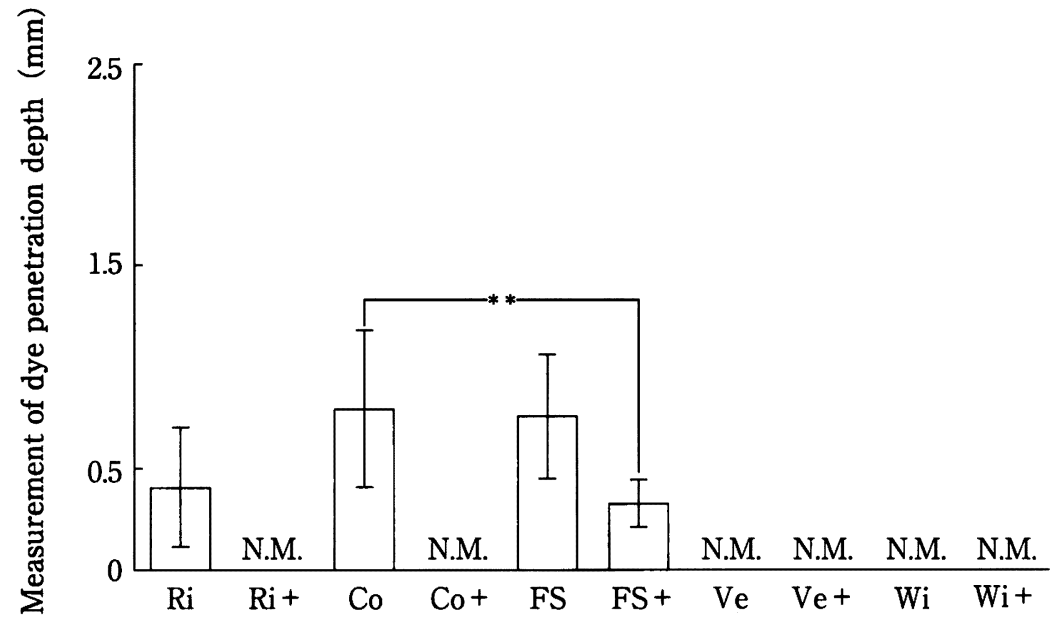

Statistical

significance with

Kruskal-Wallis

test

** $: p>0.05$

$\mathrm{n}=5$

N.M. $=$ Not

measurable

Reinforcing materials

図 5 Effect of reinforcing materials on the measurement of dye penetration (without thermal cycling test)

色素侵入試験の結果（熱サイクル負荷：なし）

物性試験は湿潤状態で行っており，湿潤状態の機械 的強さは乾燥状態と比較し，20～40\% 低い值になる といわれている ${ }^{15)}$.このことから, 今回の実験条件は 口腔内に近似していると思われる.

本実験では，AC を湿熱重合方式（以下湿熱式）に て, $65^{\circ} \mathrm{C} 60$ 分, $100^{\circ} \mathrm{C} 30$ 分の二段階加熱とし, 冷却 方法は，物性に対する影響を考慮し，大気中放冷を選 択した. Wi，Wi+は重合後肉眼的にみても収縮を生 じ，反り返り変形を起こしたが，緘維製補強材は肉眼 的にみて反り返り変形は認められなかった。本実験で は Wi，Wi+の試料について平板状に仕上げたのち, 実験に供した。実際にレジン床義歯を製作する際，こ のような操作はなく，口腔内に装着するレジン床義歯
の破折強度は本実験結果と異なると考えられる。しか しながら，色素侵入量に対してはエメリーペーパーに よる研磨の影響はないと思われる。また，重合の合計 時間 90 分が歯科理工学的には必ずしも適切とはいえ ないが，臨床で行われている時間を考えるとこの条件 は妥当であると思われる。

レジンにとって吸水性は不可避な問題であるが，特 に今回用いた湿熱式は，重合に温水を使用するため大 きな問題となる. 現在, 石高を乾燥させ重合を行うシ ステムが開発され，良好な適合性を得ることが報告さ れており ${ }^{16)}$ ，湿熱式はレジンの物性のみならず適合の 面でも不利な要因を含んでいる，しかしながら，現状 では各種重合システムは広く行きわたっておらず，本 


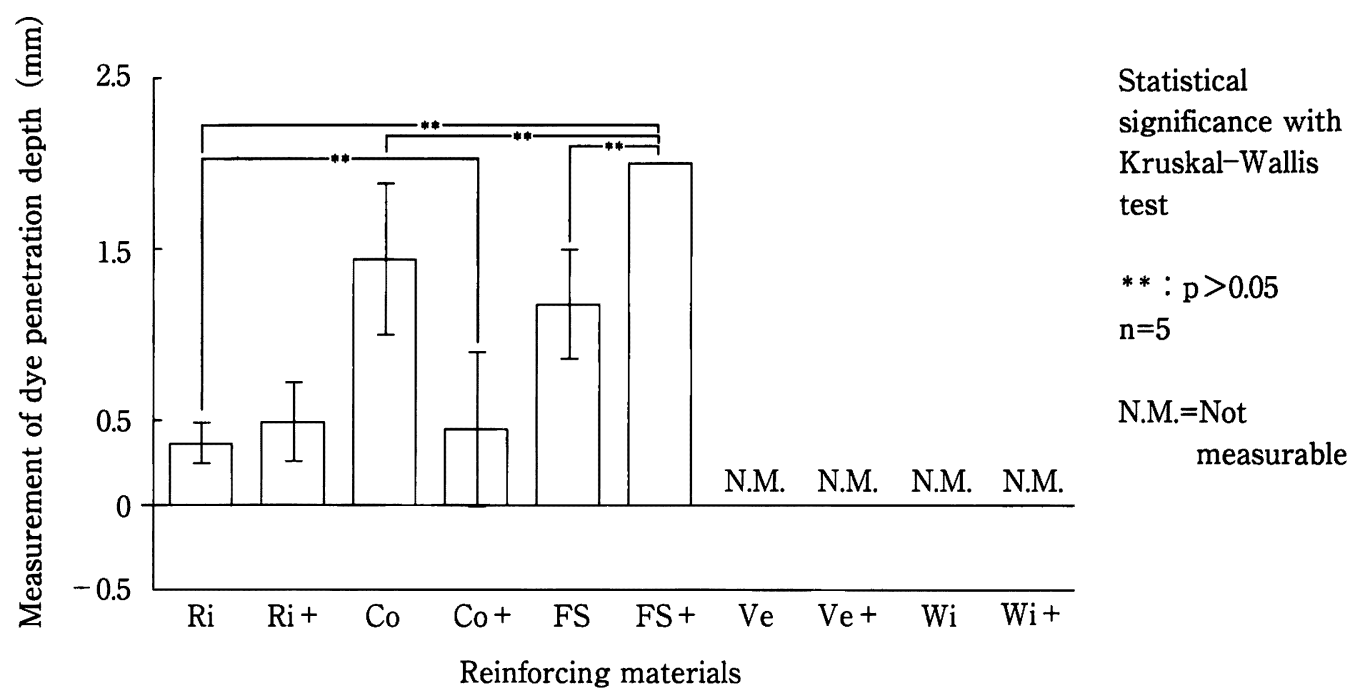

図 6 Effect of reinforcing materials on the measurement of dye penetration (with thermal cycling test)

色素侵入試験の結果（熱サイクル負荷：あり）

実験では現在でも主流であると思われる湿熱式を選択 した.

一方，レジン床義歯では義歯床の形態やこれに加わ る応力分布などの要因があり，これらすべてについて 検討することが好ましいと考えられるが，こうした場 合多くの要素を考慮せねばならず, 補強材の補強効果 を検討するには複雑となる。したがって，本実験にお いては試料の形態を平板状とした。

また本実験では，義歯破折にいたるまでの各種補強 材の補強効果を知るため, 比例限界内の強度ではなく 破断時荷重から曲げ強さを求め, 比較検討した。

\section{3. 実験結果について}

熱サイクル負荷を加えなかった三点曲げ試験の結 果, Cont. に対し有意差が認められなかったのは $\mathrm{Ri}, \mathrm{Ri}+$, Co, FS, Wi であった.このことから， Ri においては今回使用した以外の接着剤の使用が好 ましいと考えられた，Wiにおいては接着剤を使用す ることにより，曲げ強さは低下した。このことは， SB によりWi の空隙を埋めてしまったためと考えら れる. 本実験結果からは, SBよりも金属接着プライ マーのような材料が適切であると思われるが，金属接 着プライマー単体で使用せず，歯冠用硬質レジンの Opaque 材や歯科コンポジットレジン用接着材料 CLEARFIL LINER BOND II（クラレ）などとの併
用を推奨する報告 ${ }^{17)}$ もる。しかしながら，この方法 では Wi の空隙を埋める可能性があり, SB を使用し た状態と同様になるため, 曲げ強さは低下すると考え られる。

また，熱サイクル負荷を加えるとCont. の曲げ強さ は著しく低下するのに対し，補強材を使用した試料の 曲げ強さは若干低下するにとどまった。このことか ら, どの補強材を用いても補強効果は得られることが 示唆された。

南ら ${ }^{18)}$ は，金属製補強線やFS を用いた補修後の床 用レジンの曲げ強さを検討し，FS は柔軟なため補強 効果を発揮しにくいと報告している. 本実験でもFS の補強効果が認められたのは接着剤を使用したときの みであり，同様の結果となった。 また，加藤ら ${ }^{19}$ は床 用材料と金属製補強線を組合せ，反復荷重時のたわみ 量により補強効果を検討している，金属製補強線を使 用するとたわみ量が抑えられ，補強効果が得られると しているが，本実験では熱サイクル負荷を加えない場 合, Wi の補強効果は認められず異なった結果となっ た.これは試験方法の違いであると思われた。

三点曲げ試験の破折試料をみると, Ri，Co は破折 後も補強材が切断されておらず，ポリエチレンファイ バー製補強材が高い伸展性をもつことが示唆された。 逆に，グラスファイバー製補強材は AC の破折とと もに切断された（図 7).レジン床義歯の破折を考慮 


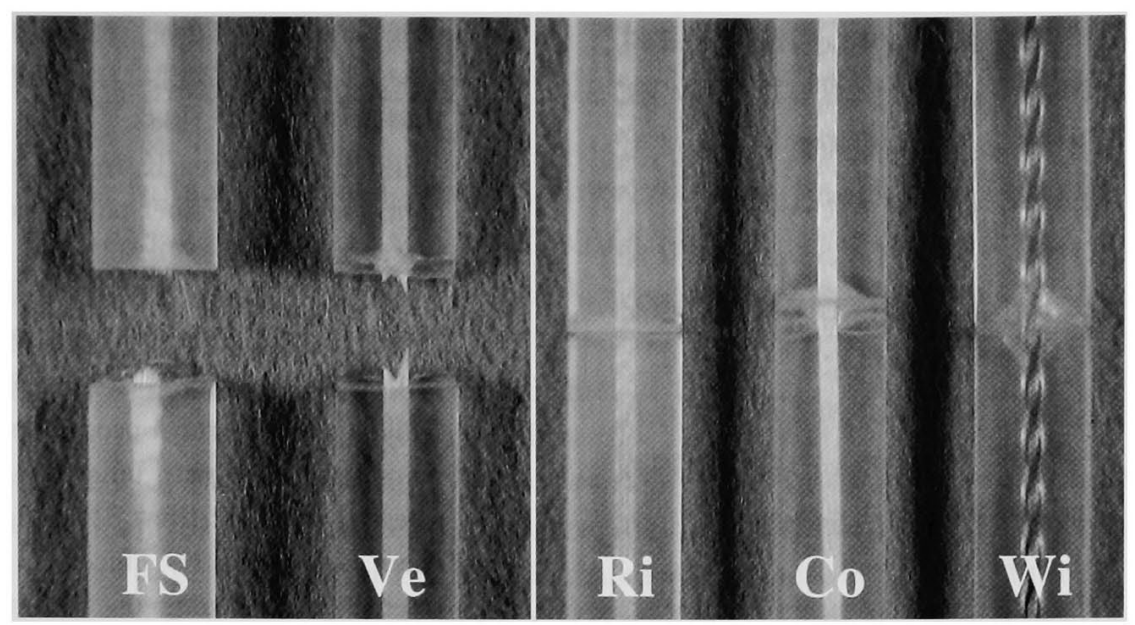

図 7 Specimens for flexural strength test 三点曲げ試験の結果

した際, 補強材は切断されないほうが望ましく, 義歯 破折により補強材の物性が低下しないのであれば，ポ リエチレンファイバー製補強材が適切であると思われ る.Wi は変形していたが，臨床においてWiのよう な太い補強線が使用されている場合，破折しても補強 線の変形まで起こしているものは少なく, Wi も有用 な補強材であると考えられた。

本実験では, 補強材の埋入位置を補強効果が得られ にくいと報告されている ${ }^{2)} \mathrm{AC}$ の厚さの中央部を選択 したが, Cont.に対し, $\mathrm{Co}+, \mathrm{FS}+, \mathrm{Ve}, \mathrm{Ve}+$, $\mathrm{Wi}+に お い て$ 有意差が認められた。 また, 熱サイク ル負荷を加えても，補強材を使用した試料の曲げ強さ は若干低下するにとどまったため, 実際の臨床では本 実験結果よりよい結果が得られると考えられた。

各種補強材の低加圧ならびに加圧重合による断面積 変化を比較した結果, 繊維製補強材は填入圧により強 く圧縮されており，このことが曲げ強さに影響してい る可能性が示唆された。また, FS の断面積減少率は 大きく,グラスファイバー繊維の編み方が疎密である と考えられた. 本実験の試料は AC の断面積に対し, 線維性補強材の断面積が小さく, $\mathrm{AC}$ の曲げ強さが大 きく関与していると考えられ, 線維製補強材自体の補 強効果を精査することができなかった可能性がある. 今後 $\mathrm{AC}$ の断面積を減じた試料について実験を行う 必要性のあることが示唆された。

色素浸入試験の結果, 熱サイクル負荷を加えない $\mathrm{Ri}, \mathrm{Co}, \mathrm{FS} に$ 色素浸入が認められたが，接着剤を使 用することにより $\mathrm{Ri}, \mathrm{Co}$ の色素浸入は認められな
かった. FSの数值は減少したが色素浸入が認めら れ，接着剤の効果は期待できないと考えられた。

熱サイクル負荷を加えた色素浸入試験の結果, 接着 剤の効果が認められたのはCo のみであり, ほかの繊 維製補強材は色素浸入量が増加する傾向が認められ た.このことより, Ri, FS はそのほかの接着方法を 考慮しなければならないことが示唆された.

また，熱サイクル負荷の有無にかかわらず，Ve, Wi は色素浸入が認められず良好な接着ならびに嵌合 を得ていると思われた，しかし，Wi は化学的結合で はないため，熱サイクル負荷時間を長くすることによ り色素浸入量は増加すると考えられる.また, 口腔内 では義歯に対し熱負荷と曲げ応力が同時に加わってお り，1つの試料に対し両方の負荷を加えた場合, 色素 浸入量は増加すると思われる。

一連の実験結果から, 各種補強材による床用レジン の補強効果を得るためには, より優れた接着剤の選択 が必要であると考えられた．また，繊維製補強材を用 いて新製義歯を製作する際, 作業用模型への位置決め やレジン填入圧による位置の変化といった問題があ り, 本実験結果のみで繊維製補強材の実用性を評価す ることは危険であるため, 今後詳細に検討する必要が あると思われた。

\section{V. 結 論}

各種補強材によるレジン床義歯の補強効果を検討す る目的で本研究を行った結果, 次の結論が得られた。 
1. 熱サイクル負荷を加えると Cont. の曲げ強さは 著しく低下したが，補強材を使用した試料の曲 げ強さの低下は少なく，どの補強材を用いても 補強効果が得られることが示唆された。

2. Wiにおいては，SBを使用することにより曲 げ強さは低下し，この原因として Wi の空隙を 埋めてしまったことが考えられた。

3. 色素浸入試験の結果, 接着剂の効果が認められ たのはCoのみであり，そのほかの繊維製補強 材については, ほかの接着方法を考慮しなけれ ばならないと思われた。

4. レジン床義歯の破折を考慮した場合，破折とと もに切断されるグラスファイバー製補強材より 切断されないポリエチレンファイバー製補強材 や金属製補強材のほうが適切であることが示唆 された。

なお本論文要旨は, 第 102 回日本補経歯科学会学術大会（平 成 11 年 10 月 22 日, 名古屋) ならびに平成 12 年度日本補経歯 科学会東海支部学術大会（平成 12 年 12 月 10 日, 名古屋）に おいて発表した。

\section{文献}

1）豊田 實, 杉村大介, 青木太郎ほか。義歯補強線と接着 性レジンとの関係について。神奈川歯学 $30 ： 286-292$, 1995.

2）寺岡文雄. 徹底検証 レジン床のすべて $170-178$, 東 京: 医歯薬出版, 1999.

3）岡田政俊, 前田芳信, 野首孝祠ほか. 加熱重合型接着性 レジンに関する研究ーレジン床義歯におけるコバルトク ロム線の補強効果について一. 補綴誌 $29: 78-84,1985$.

4）中平良基, 前田芳信, 岡田政俊ほか. 常温重合型接着性 レジンの有床義歯への応用一補強線埋入による流し込み レジン床の補強効果一. 補綴誌 $30: 235-241,1986$.

5）中平良基, 前田芳信, 岡田政俊ほか. 常温重合型接着性 レジンの有床義歯への応用一修理時の補強線の効果一. 補緅誌 $30 ： 1190-1197,1986$.

6）下里隆史，山中 彬，倉田茂昭ほか，炭素絨維クロス補 強による義歯床用 PMMA レジン一第 1 報 クロス表面 処理と補強レジンの曲げおよび引張強さへの影響一，歯 材器 $3: 648-654,1984$.

7）岡野雅一, 矢崎貴啓, 河相安彦ほか. アラミド瀻維の義
歯床への応用一第 2 報 表面処理緎維およびその混入量 がレジン床の補強効果に与える効果について一．日大口 腔科学 $14: 46-53,1988$.

8) Vallittu PK, Narva K. Impact strength of a modified continuous glass fiber-poly (methyl methacrylate). Int J Prosthodont 10:142-148, 1997.

9）松尾 陽，五味治徳，砂田徳保ほか．GFRによる臼歯 部用硬質レジンの機械的性質 第 1 報 曲げ強度, 引張 強度について. 補経誌 $42 \cdot 100$ 回特別号：178, 1998.

10) Vallittu PK. Flexural properties of acrylic resin polymers reinforced with unidirectional and woven glass fibers. J Prosthet Dent 81 : 318-326, 1999.

11) Uzun G, Hersek N, Tincer T. Effect of five woven fiber reinforcements on the impact and transverse strength of a denture base resin. J Prosthet Dent 81 : 616-620, 1999.

12）堀越直文, 古谷彰伸, 割田研司ほか. グラスファイバー による即時重合レジンの補強効果について. 補緅誌 $43 \cdot 102$ 回特別号：214, 1999.

13) Bas J-M, Kim K-N, Hattori $M$ et al. The flexural of fiber-reinforced composite with light-polymerized polymer matrix. Int J Prosthodont 14:33-39, 2001.

14) Nagai E, Otani K, Satoh $Y$ et al. Repair of denture base resin using woven metal and glass fiber : Effect of methylene chloride pretreatment. J Prosthet Dent $85: 496-500,2001$.

15）歯科理工学会編. 歯科理工学 第 2 版 256-258, 東京： 医歯薬出版, 1982.

16）寺岡文雄. 適合精度を追求した重合システムーその 1 . DS システムの基䃈と概念. QDT 18：457-475, 1993.

17）岡崎卓司. 誌上テーブルクリニック ブース 9 重合. 村 岡秀明編，無歯䫜臨床一技を妨むむ/デンタルダイヤ 増刊号 101-114, 東京：デンタルダイヤモンド社, 1998.

18）南弘之, 倉茂尚徳, 嶺崎良人ほか. 補強線を用いて補 修した床用レジンの曲げ強さ. 補緅誌 $45 \cdot 106$ 回特別 号：98, 2001.

19）加藤謙一, 佐久間崇之, 長山克也. 床用材料における補 強線の効果について. 補緅誌 $43 \cdot 101$ 回特別号：144, 1999.

著者連絡先：酒匂 充夫

于399-0781 長野県塩尻市広丘郷原 1780

TEL : 0263-51-2046

FAX : 0263-51-2046

E-mail : sakoh@po.mdu.ac.jp 


\title{
Effect of Various Reinforcing Materials for Resin Denture Base
}

\author{
Sakoh Mitsuo, Kaida Takehiko, Kuroiwa Akihiro, Takai Tomoyuki, \\ Uda Go, Minemura Takashi, Yoshida Shigeo, Igarashi Yoshimasa, \\ Ito Michio*, Hibino Yasushi**, Hachikawa Masato*** and Ogata Akira**** \\ Department of Removable Prosthodontics, School of Dentistry, Matsumoto Dental University \\ (Chief : Prof. Igarashi Yoshimasa) \\ *Department of Dental Materials, School of Dentistry, Matsumoto Dental University \\ ${ }^{* *}$ Department of Dental Materials Science, Meikai University, School of Dentistry \\ ***Tokyo Branch (Hachikawa Dental Clinic) \\ ****Kansai Branch (Ogata Dental Clinic)
}

\section{ABSTRACT}

J Jpn Prosthodont Soc 48:592-601, 2004

Purpose : This study evaluated the effect of reinforcing materials on the mechanical strength of acrylic resin denture base (polymethylmethacrylate; PMMA). Three reinforcing materials were embedded in the heat-cure acrylic resin : polyethylene fiber-PMMA composite, glass fiber-PMMA, and strengthener-PMMA hybrid composite. The flexural strength test and dye penetration test were applied to each reinforced specimen.

Methods : Rectangular test specimens were modified by incorporating additional reinforcing materials : untreated polyethylene fibers, glass fibers, and strengthener. The same size of acrylic specimen without any reinforcing material was selected as a control. The flexural strength test was executed with Auto Graph AG-5000 (Shimadzu) after storing the specimens in water at $37^{\circ} \mathrm{C}$ for two weeks. The dye penetration test of the specimens was evaluated by measuring with a Profile Projector PJ 311 (Mitutoyo) after storing them in a 3\% aqueous solution of basic fuchsin dye for 72 hours.

Results and Conclusions: The results suggested that reinforcing materials enhanced the flexural strength of PMMA, while the use of additional fiber reinforcement made of polyethylene or glass fibers in the test specimens did not affect the flexural strength. The additional reinforcing materials of the test specimen did affect the flexural strength.

\section{Key words}

acrylic resin denture base, reinforcing materials, flexural strength, dye penetration 